\title{
Analisis Laju Perkecambahan Kacang Tanah (Arachis hypogaea (L.) Merr.) yang Diberikan Kombinasi Perlakuan Suhu dan Lama Perendaman Asap Cair (Liquid Smoke)
}

\section{Analysis of Peanut (Arachis hypogaea (L.) Merr.) Germination Velocity Treated with Temperature and Duration of Liquid Smoke Soaking}

\author{
Basry Yadi Tang ${ }^{1}$, Stormy Vertygo ${ }^{2 *}$, Abner Tonu Lema ${ }^{2}$, Wahyu Dani Swari ${ }^{3}$ \\ ${ }^{1}$ Jurusan Manajemen Pertanian Lahan Kering, Politeknik Pertanian Negeri Kupang, \\ ${ }^{2}$ Jurusan Peternakan, Politeknik Pertanian Negeri Kupang, \\ ${ }^{3}$ Program Studi Pendidikan Matematika, Universitas Muhammadiyah Kupang. \\ *E-mail : svertygo91@gmail.com
}

\begin{abstract}
The research aims to get to analyze the effect of temperature and liquid smoke soaking combination on the velocity of peanut germination. Parameters measure were; Mean Germination Time (MGT), Mean GerminationRate (MGR), Final Germination Percentage $(G T)$, Coefficient Velocity of Germination (CVG), Germination Rate Index (GRI). The treatment combinations used were temperature $25^{\circ} \mathrm{C}(1), 30^{\circ} \mathrm{C}(2), 35^{\circ} \mathrm{C}$ (3) dan $40^{\circ} \mathrm{C}$ (4) and liquid smoke in which the seeds were soaked for 1 hour (a), 2 hours (b) and 3 hours (c). This resulted in 12 treatment combinations. Results showed that the best treatments were control $1\left(K_{0} 25^{\circ} \mathrm{C}\right)$, control $4\left(K_{0} 40^{\circ} \mathrm{C}\right)$ and $4 a\left(K_{1} 40^{\circ} \mathrm{C}\right)$, with germination velocity as follows: $1.67 \mathrm{~cm}^{-d a y^{-1}}, 1.50 \mathrm{~cm} . d a y-1$ and $2.00 \mathrm{~cm}$.day 1 respectively. However, it is recommended to use soaking in liquid smoke for an hour (1a) to further initiate germination development that could hopefully lead to a much higher peanut crop yield during cultivation.
\end{abstract}

Keywords: Germination velocity, Liquid smoke, Peanuts, Temperature.

Disubmit : 30 November 2019; Diterima: 17 Desember 2019; Disetujui : 14 Januari 2020

\section{PENDAHULUAN}

Pembudidayaan tanaman kacang tanah umumnya dilakukan di lahan kering pada berbagai jenis tanah, suhu dan curah hujan. Media tanah yang baik bagi pertumbuhannya adalah yang berkarakteristik tanah sedang, remah, gembur dengan drainase yang baik yang tidak akan menggenangkan air saat irigasi. Suhu optimum bagi pertumbuhan tanaman ini adalah yang berkisar antara 21-27. Pertumbuhan bunga yang akan terhenti pada suhu di atas $34 \mathrm{oC}$. Sebagian besar tanaman Kacang tanah yang ditanam di lahan kering dilakukan pada musim penghujan sedangkan sebagian kecilnya yang ditanam pada lahan sawah irigasi dilakukan pada musim kemarau. Pemanenan dapat dilakukan setelah 4 - 5 bulan penanaman (Mussadad, 2005., Rahmianna et al, 2015., Trustinah, 2015., Malone, 2019).

Pembudidayaan dan pemanfaatan Kacang tanah di NTT cukup diminati masyarakat karena beberapa hal di antaranya: Teknik budidaya yang cukup mudah, relatif cepat dipanen, toleran terhadap kekeringan, mudah dipasarkan dengan nilai jual cukup tinggi serta dapat dimanfaatkan dalam berbagai bentuk olahan makanan seperti kue kering dan kue basah, roti, es krim, bumbu masakan dan camilan. Akan tetapi, dengan 
berbagai keuntungan di atas bukan berarti membuat proses pembudidayaan Kacang tanah di NTT tanpa hambatan. Badan Pengkajian Teknologi Pertanian (BPTP) Nusa Tenggara Timur mencatat bahwa tekstur tanah yang berbatu-batu, rendahnya aplikasi atau penggunaan teknologi budidaya serta curah hujan yang semakin sedikit dapat mengancam produktivitas Kacang tanah di wilayah NTT. Berdasarkan data dari Badan Pusat Statistik Provinsi NTT, produksi kacang tanah di NTT pada tahun 2017 adalah sebanyak 10.445 ton/tahun. Jumlah ini menurun sebanyak $\pm 40 \%$ sejak tahun 2013 yaitu sebanyak 16.056 ton/tahun (BPS, 2017). Selain itu, teknik pembudidyaan yang dilakukan oleh petani kacang tanahpun masih menggunakan metode konvensional yang semakin menurunkan produktivitasnya. Hal ini menjadi salah satu landasan perlu adanya pengembangan aplikasi teknologi sederhana tepat-guna yang diperuntukkan bagi tercapainya efektivitas produksi pangan tumbuhan tersebut. Salah satunya dengan mengembangkan aplikasi teknologi pengasapan terhadap benih kacang tanah sebelum dibudidayakan. Banyak studi yang telah membuktikan dampak positif pengasapan dalam mendorong germinasi atau perkecambahan pada berbagai jenis tumbuhan. Berbagai senyawa yang terkandung di dalam asap pembakaran material tumbuhan (misalnya karrikin dan cyanohydrin) akan bertindak sebagai ligan yang menginduksi serangkaian jalur metabolik sehingga mempengaruhi kondisi fisiologis suatu benih yang membuatnya lebih cepat berkecambah. Telah banyak studi yang mengkonfirmasi pengaruh pengasapan dalam mendorong germinasi berbagai jenis tumbuhan berbunga (angiospermae) (van Staden et al., 2006., Chumpookam et al., 2012., Zhou et al., 2014., Elsadek and Yousef, 2019., Soós et al., 2019). Beberapa senyawa kimia telah diketahui yang terkandung di dalam asap pembakaran material tumbuhan yang memiliki aktivitas sebagai faktor tumbuh (Growth Factor) exogenous, diantaranya: karrikin dan cyanohydrin (Flematti et al., 2013., Flematti et al., 2015).

Harapannya dengan teknologi pengasapan ini dapat memacu laju perkecambahan, Dengan asumsi bahwa semakin tinggi laju perkecambahan maka semakin besarpula pertumbuhan dan perkembangannya. Besarnya laju perkecambahan tersebut dapat ditentukan berdasarkan beberapa parameter terkait yaitu dengan mengukur dan menghitung Rerata laju perkecambahan (MGT), Koefisien kelajuan germinasi (CVG) dan Indeks laju germinasi (GRI) (Al-Ansari and Ksiksi, 2016).

\section{METODE PENELITIAN}

Penelitian ini telah dilakukan kurang lebih selama 2 bulan yaitu bulan Agustus 2019 sampai dengan September 2019. Tempat penelitian dilakukan di Laboratorium TPT dan Laboratorium Umum Politani Kupang. Adapun tahapan penelitian yang dilakukan yaitu: Seleksi Benih; Dalam penelitian ini akan digunakan 76 biji kacang tanah dari varietas yang sama (Varietas Deli) dengan ukuran yang relatif sama pula. Sterilisasi Pembenihan (Pretreatment) (Iqbal et al., 2016); Biji kacang tanah di rendam dalam larutan Sodium Hipoklorit 10\% selama 5 menit kemudian dibilas dengan air destilasi dan dikeringkan dengan kertas saring. Kombinasi Perlakuan Pembenihan (Treatment); Terdapat 2 jenis perlakuan yang akan diberikan terhadap biji kacang tanah yaitu: Perlakuan I : Suhu dengan 4 sub perlakuan yaitu : $25^{\circ} \mathrm{C}(1), 30^{\circ} \mathrm{C}(2), 35^{\circ} \mathrm{C}$ (3) dan $40{ }^{\circ} \mathrm{C}$ (4). Perlakuan II : Lama pengasapan (liquid smoke) dengan 3 sub perlakuan yaitu : 1 jam (a), 2 jam (b) dan 3 jam (c). Kombinasi perlakuan yang digunakan adalah pada suhu $25^{\circ} \mathrm{C}(1), 30^{\circ} \mathrm{C}(2), 35^{\circ} \mathrm{C}(3)$ dan $40^{\circ} \mathrm{C}$ (4) dan lama perendaman dalam asap cair (liquid smoke) selama 1 jam (a), 2 jam (b) dan 3 jam (c). Masing-masing kelompok kombinasi perlakuan terdiri dari 4 ulangan (total : 48 biji).

Selanjutnya terdapat 5 parameter yang akan di hitung nilainya yaitu: (Al-Ansari and Ksiksi, 2016., (Al-Mudaris, 1998):

Rerata Waktu Berkecambah (MGT) $: M G T=\frac{2 t x}{2 t}$

\begin{tabular}{|c|c|c|}
\hline \multirow[t]{2}{*}{ Keterangan } & MGT & : Rerata Waktu Berkecambah (hari) \\
\hline & & : Jumlah biji berkecambah pada hari ke \\
\hline & $f$ & : Jumlah biji berkecambah \\
\hline
\end{tabular}


Rerata Laju Germinasi (MGR) $: M G R=\frac{\mathrm{CVG}}{1 \mathrm{UU}}=\frac{1}{M G I}$

Keterangan : $\quad$ MGR : Rerata Laju Germinasi $\left(\mathrm{cm} \cdot\right.$ hari $\left.^{-1}\right)$

CVG : Koefisien Kelajuan Germinasi

MGT : Rerata Waktu Germinasi

Persentase Germinasi Akhir (GT) :

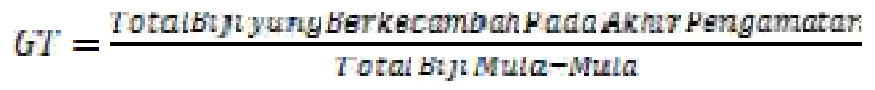

Keterangan : $\quad$ GT $\quad$ : Persentase Germinasi Akhir (\%)

Koefisien Kelajuan Germinasi (CVG) :

$$
C V G=\frac{\left(N_{1}+N_{2}+\cdots+N_{i}\right)}{100} x\left(N_{1} T_{1}+N_{2} T_{2}+\ldots+N_{i} T_{i}\right)
$$

Keterangan : $\quad$ CVG $\quad$ : Koefisien Kelajuan Germinasi

$\mathrm{N} \quad$ : Jumlah biji berkecambah setiap harinya

T : Jumlah Hari Pengamatan

Indeks Laju Germinasi (GRI) $: G R I=\frac{G_{1}}{I}+\frac{G_{2}}{2}+\cdots+\frac{G_{i}}{i}$

$$
\begin{array}{lll}
\text { Keterangan : } & \text { GRI } & \text { : Indeks Laju Germinasi } \\
& \text { G } & \text { : Presentase Germinasi Pada hari ke-x }
\end{array}
$$

\section{HASIL DAN PEMBAHASAN}

Berdasarkan hasil penelitian yang dilakukan terdapat lima parameter yang telah dihitung, diantaranya yaitu rerata waktu berkecambah, indeks perkecambahan, persentase germinasi akhir, koefisien perkecambahan dan laju perkecambahan. Adapun data yang telah diperoleh yaitu data hasil pengukuran germinasi dari biji kacang tanah untuk setiap harinya. Terdapat dua kombinasi perlakuan yang diberikan yaitu perlakuan dengan memvariasikan suhu pada $25^{\circ} \mathrm{C}, 30^{\circ} \mathrm{C}, 35^{\circ} \mathrm{C}$ dan $40^{\circ} \mathrm{C}$ terhadap lama perendaman yaitu tanpa perendaman dengan asap cair (dalam hal ini sebagai variabel kontrol), perendaman dengan asap cair selama 1 jam, 2 jam dan 3 jam. Adapun data yang diperoleh sebagai berikut:

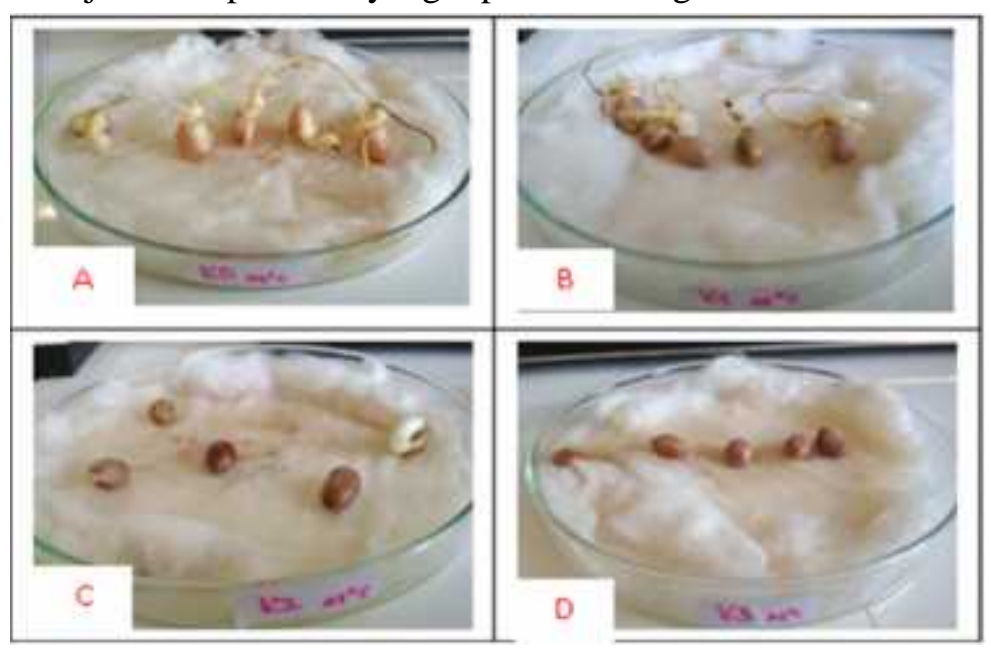

Gambar 1. Perlakuan Perkecambahan Menurut Suhu $25^{\circ} \mathrm{C}$ tanpa perendaman (A), perendaman dengan asap cair selama 1 jam (B), 2 jam (C) dan 3 jam (D)

Pada suhu $25^{\circ} \mathrm{C}$ (Gambar 1), perlakuan terbaik dalam memacu pertumbuhan perkecambahan benih adalah perlakuan A (tanpa perendaman) dan perlakuan B (perendaman 1 jam). Akan tetapi, pada perlakuan $\mathrm{B}$, terlihat bahwa perkembangan akar kecambah lebih pesat yang ditandai oleh lebih banyaknya cabang akar (akar lateral) yang terbentuk. 


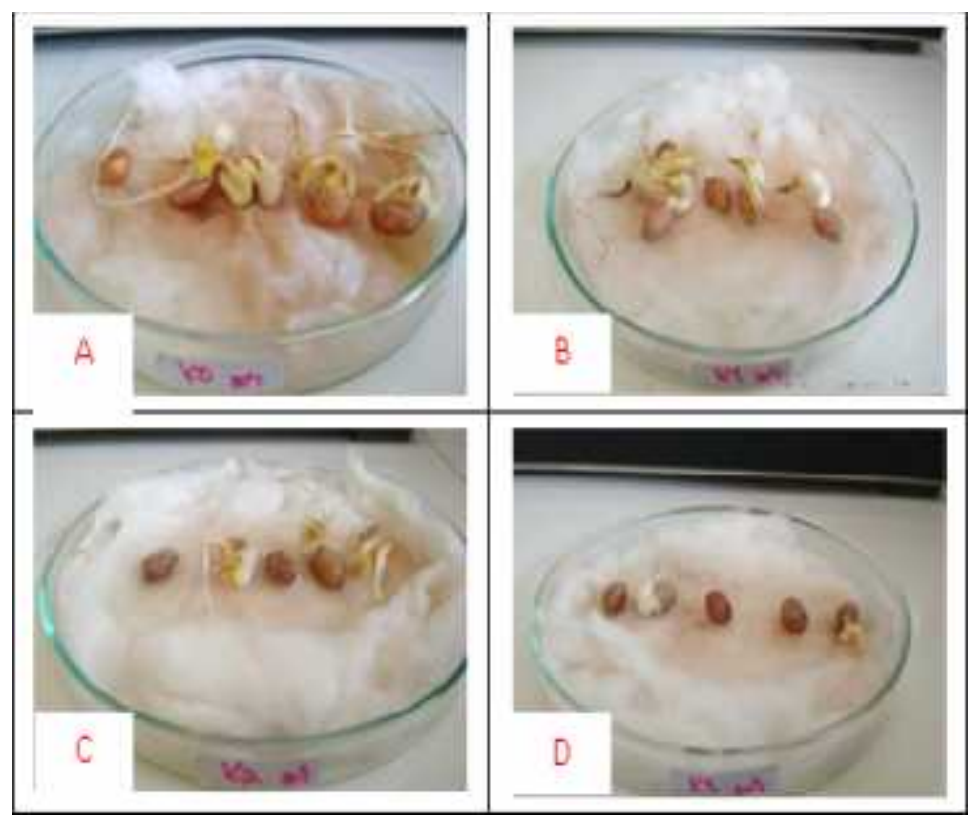

Gambar 2. Perlakuan Perkecambahan Menurut Suhu $30^{\circ} \mathrm{C}$ tanpa perendaman (A), perendaman dengan asap cair selama 1 jam (B), 2 jam (C) dan 3 jam (D)

Suhu $30^{\circ} \mathrm{C}$ (Gambar 2), juga menunjukkan hasil yang sama dengan suhu 25oC dimana perlakuan tanpa perendaman (A) memberikan hasil yang terbaik. Namun, apabila dilihat secara lebih seksama, meskipun perlakuan perendaman 1 jam (B) memiliki laju pertumbuhan yang sedikit lebih rendah dari perlakuan A, pangkal akar kecambah pada perlakuan B memiliki diameter yang lebih besar.

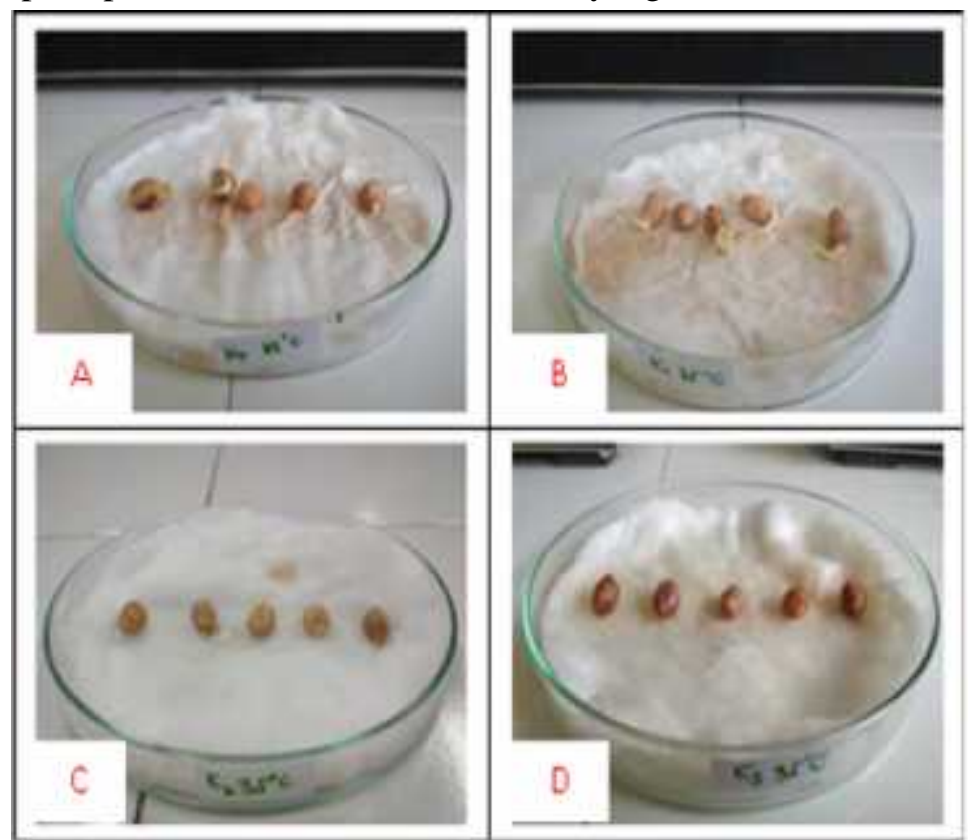

Gambar 3. Perlakuan Perkecambahan Menurut Suhu $35^{\circ} \mathrm{C}$ tanpa perendaman (A), perendaman dengan asap cair selama 1 jam (B), 2 jam (C) dan 3 jam (D)

Pada suhu $35^{\circ} \mathrm{C}$ (Gambar 3), perlakuan tanpa perendaman (A) dan perendaman 1 jam (B) masih memberikan hasil terbaik dalam mendorong perkecambahan benih kacang tanah, meskipun masih dalam laju yang sangat lambat dibandingkan dengan pada suhu $25^{\circ} \mathrm{C}$ dan $30^{\circ} \mathrm{C}$. 


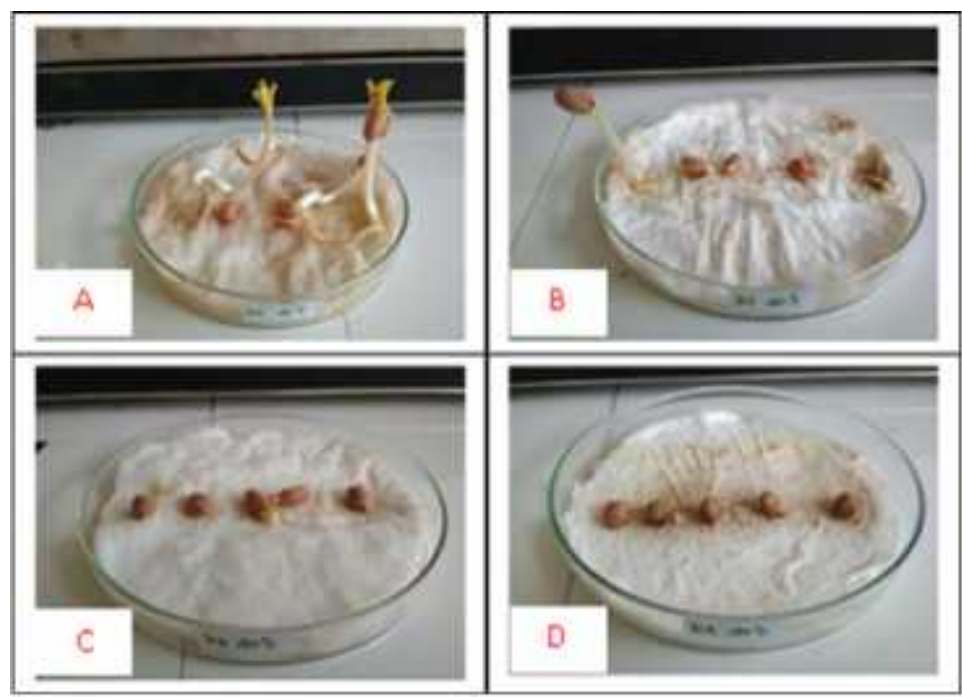

Gambar 4. Perlakuan Perkecambahan Menurut Suhu $40^{\circ} \mathrm{C}$ tanpa perendaman (A), perendaman dengan asap cair selama 1 jam (B), 2 jam (C) dan 3 jam (D)

Pada suhu $40^{\circ} \mathrm{C}$ (Gambar 4), perlakuan tanpa perendaman (A) memberikan hasil yang paling baik yang ditunjukkan dengan tidak hanya pertumbuhan radikula (calon akar) yang pesat tetapi juga dengan munculnya plumula (calon pucuk).

Tabel 1. Hasil Analisis Parameter Germinasi untuk suhu $25^{\circ} \mathrm{C}$

\begin{tabular}{llcccc}
\hline No & Parameter & $\mathbf{K}_{\mathbf{0}}$ & $\mathbf{K}_{\mathbf{1}}$ & $\mathbf{K}_{\mathbf{2}}$ & $\mathbf{K}_{\mathbf{3}}$ \\
\hline 1. & Rerata Waktu Berkecambah (MGT) & 3,00 & 3,80 & 7,50 & 0,00 \\
2. & Rerata Laju Germinasi (MGR) & 1,67 & 1,50 & 0,40 & 0,00 \\
3. & Persentase Germinasi Akhir (GT) & 100 & 100 & 40 & 0 \\
4. & Koefisien Laju Germinasi (CVG) & 0,75 & 0,95 & 0,30 & 0,00 \\
5. & Indeks Laju Germinasi (GRI) & 33,33 & 28,00 & 6,00 & 0,00 \\
\hline
\end{tabular}

Hasil analisis parameter germinasi pada Tabel 1, menunjukkan bahwa kombinasi perlakuan dengan suhu 250C dan tanpa perendaman benih kacang tanah (K0) memberikan nilai rerata laju perkecambahan (MGR) sebesar 1,67 cm.hari-1, sedangkan untuk lama perendaman dengan dengan larutan asap cair selama 1 jam diperoleh nilai rerata laju perkecambahan sebesar 1,50 cm.hari-1. Secara umum dapat terlihat bahwa pada suhu 250C K0 memiliki rerata laju perkecambahan yang lebih besar dibandingkan dengan K1, hal ini menunjukkan bahwa pada suhu ini perendaman dengan larutan asap cair tidak memberikan pengaruh yang signifikan.

Tabel 2. Hasil Analisis Parameter Germinasi untuk suhu $30^{\circ} \mathrm{C}$

\begin{tabular}{llcccc}
\hline No & Parameter & $\mathbf{K}_{\mathbf{0}}$ & $\mathbf{K}_{\mathbf{1}}$ & $\mathbf{K}_{\mathbf{2}}$ & $\mathbf{K}_{\mathbf{3}}$ \\
\hline 1. & Rerata Waktu Berkecambah (MGT) & 3,00 & 4,40 & 6,25 & 6,50 \\
2. & Rerata Laju Germinasi (MGR) & 1,33 & 1,36 & 0,65 & 0,33 \\
3. & Persentase Germinasi Akhir (GT) & 80 & 100 & 80 & 40 \\
4. & Koefisien Laju Germinasi (CVG) & 0,48 & 1,10 & 1,04 & 0,26 \\
5. & Indeks Laju Germinasi (GRI) & 26,67 & 27,22 & 13,36 & 6,50 \\
\hline
\end{tabular}

Tabel 2 menunjukkan bahwa, perlakuan dengan suhu 300C dan tanpa perendaman benih kacang tanah (K0) memberikan nilai rerata laju perkecambahan (MGR) sebesar 1,33 cm.hari-1, sedangkan untuk lama 
perendaman dengan dengan larutan asap cair selama 1 jam diperoleh nilai rerata laju perkecambahan sebesar $1,36 \mathrm{~cm}$.hari-1. Secara umum dapat terlihat bahwa pada suhu 300C K1 memiliki rerata laju perkecambahan yang lebih besar dibandingkan dengan K0, hal ini menunjukkan bahwa pada suhu ini perendaman dengan larutan asap cair memberikan pengaruh yang cukup signifikan.

Tabel 3. Hasil Analisis Parameter Germinasi untuk suhu $35^{\circ} \mathrm{C}$

\begin{tabular}{llcccc}
\hline No & Parameter & $\mathbf{K}_{\mathbf{0}}$ & $\mathbf{K}_{\mathbf{1}}$ & $\mathbf{K}_{\mathbf{2}}$ & $\mathbf{K}_{\mathbf{3}}$ \\
\hline 1. & Rerata Waktu Berkecambah (MGT) & 5,67 & 3,25 & 0,00 & 0,00 \\
2. & Rerata Laju Germinasi (MGR) & 0,77 & 1,33 & 0,00 & 0,00 \\
3. & Persentase Germinasi Akhir (GT) & 60 & 80 & 0 & 0 \\
4. & Koefisien Laju Germinasi (CVG) & 0,48 & 1,24 & 0,00 & 0,00 \\
5. & Indeks Laju Germinasi (GRI) & 15,36 & 26,67 & 0,00 & 0,00 \\
\hline
\end{tabular}

Hasil analisis parameter germinasi pada Tabel 3, secara umum menunjukkan bahwa pada suhu $35^{\circ} \mathrm{C}$ K1 memiliki pengaruh yang signifikan terhadap perkecambahan benih kacang tanah dengan rerata laju germinasi (MGR) 1,33 cm.hari-1 dibandingkan dengan $\mathrm{K}_{0}$.

Tabel 4. Hasil Analisis Parameter Germinasi untuk suhu $40^{\circ} \mathrm{C}$

\begin{tabular}{llcccc}
\hline No & Parameter & $\mathbf{K}_{\mathbf{0}}$ & $\mathbf{K}_{\mathbf{1}}$ & $\mathbf{K}_{\mathbf{2}}$ & $\mathbf{K}_{\mathbf{3}}$ \\
\hline 1. & Rerata Waktu Berkecambah (MGT) & 2,00 & 1,75 & 2,00 & 7,00 \\
2. & Rerata Laju Germinasi (MGR) & 2,00 & 2,50 & 1,00 & 0,14 \\
3. & Persentase Germinasi Akhir (GT) & 80 & 80 & 40 & 20 \\
4. & Koefisien Laju Germinasi (CVG) & 1,44 & 1,48 & 0,36 & 0,04 \\
5. & Indeks Laju Germinasi (GRI) & 40,00 & 50,00 & 20,00 & 2,86 \\
\hline
\end{tabular}

Pada tabel 4, hasil analisis parameter germinasi secara umum menunjukkan bahwa pada suhu $40^{\circ} \mathrm{C}, \mathrm{K}_{1}$ juga memiliki pengaruh yang signifikan terhadap perkecambahan benih kacang tanah dengan rerata laju germinasi (MGR) 2,50 cm.hari ${ }^{-1}$ dibandingkan dengan perlakuan-perlakuan lainnya. Terlihat pula bahwa secara umum pemberian asap cair tidak hanya mendorong pertumbuhan tetapi juga perkembangan akar yang ditandai dengan terbentuknya akar lateral.

Tabel 5. Laju Germinasi untuk setiap kombinasi perlakuan (Lama Perendaman $\times$ Suhu)

\begin{tabular}{ccccc}
\hline \multirow{2}{*}{ Konsentrasi } & \multicolumn{4}{c}{ Suhu } \\
\cline { 2 - 5 } & $\mathbf{2 5}^{\mathbf{C}} \mathbf{C}$ & $\mathbf{3 0}^{\mathbf{0}} \mathbf{C}$ & $\mathbf{3 5}^{\mathbf{0}} \mathbf{C}$ & $\mathbf{4 0}^{\mathbf{0}} \mathbf{C}$ \\
\hline $\mathrm{K}_{0}$ & $1,67 \mathrm{bc}$ & $1,33 \mathrm{~b}$ & $0,77 \mathrm{ab}$ & $2,00 \mathrm{bc}$ \\
$\mathrm{K}_{1}$ & $1,30 \mathrm{~b}$ & $1,36 \mathrm{~b}$ & $1,33 \mathrm{~b}$ & $2,50 \mathrm{bc}$ \\
$\mathrm{K}_{2}$ & $0,40 \mathrm{a}$ & $0,65 \mathrm{a}$ & $0,00 \mathrm{a}$ & $1,00 \mathrm{ab}$ \\
$\mathrm{K}_{3}$ & $0,00 \mathrm{a}$ & $0,33 \mathrm{a}$ & $0,00 \mathrm{a}$ & $0,14 \mathrm{a}$ \\
\hline
\end{tabular}

Berdasarkan hasil analisis sidik ragam (Tabel 5), parameter laju germinasi memberikan hasil tertinggi pada kombinasi perlakuan $\mathrm{K}_{0} 25^{\circ} \mathrm{C}, \mathrm{K}_{0} 40^{\circ} \mathrm{C}$ dan $\mathrm{K}_{1} 40^{\circ} \mathrm{C}$ dengan taraf signifikansi bc. Dengan kata lain, pemberian perlakuan tanpa perendaman $\mathrm{K}_{0}$ tidak memberikan pengaruh yang cukup signifikan apabila dibandingkan terhadap perlakuan dengan pemberian perendaman asap cair. Akan tetapi, pemberian asap cair tetap direkomendasikan karena berdasarkan hasil pengamatan, secara kualitatif kecambah dengan pemberian asap cair menunjukkan perkembangan yang jauh lebih baik dibandingkan dengan perlakuan $\mathrm{K}_{0}$. Hal tersebut 
ditandai dengan munculnya akar lateral dengan jumlah yang banyak dan dalam waktu yang relatif singkat pula.

Hasil pengamatan pemberian kombinasi perlakuan lama perendaman dan suhu terhadap laju germinasi diukur untuk setiap harinya selama 10 hari pengamatan. Berdasarkan hasil pengukuran didapatkan laju germinasi tertinggi adalah pada kombinasi perlakuan $\mathrm{K}_{1} 40^{\circ} \mathrm{C}$ sebesar $2,50 \mathrm{~cm}$.hari ${ }^{-1}$. Akan tetapi analisis statistik (ANOVA) menunjukkan bahwa nilai ini tidak berbeda nyata dengan dua perlakuan lainnya yakni $\mathrm{K}_{0}$ $25^{\circ} \mathrm{C}$ dan $\mathrm{K}_{0} 40^{\circ} \mathrm{C}$ yang laju germinasinya masing-masing sebesar $1,67 \mathrm{~cm}$.hari ${ }^{-1}$ dan 2,00 cm.hari ${ }^{-1}$. Hal ini tampaknya sejalan dengan Ghebrehiwot et al. (2008) di mana hasil eksperimen mereka menggunakan asap cair (smoke-water) terhadap benih rumput teff (Eragrosstis tef) terbukti memacu germinasi tumbuhan tersebut di bawah cekaman suhu yang tinggi (perlakuan maksimum $40^{\circ} \mathrm{C}$ ).

Parameter lain yang diukur adalah rearata waktu berkecambah (MGT) yang didefinisikan sebagai lama waktu yang dibutuhkan bagi satu benih untuk berkecambah (Al-Ansari and Ksiksi, 2016., (Al-Mudaris, 1998) Hasil pengukuran MGT menunjukkan bahwa kombinasi perlakuan $\mathrm{K}_{1} 40^{\circ} \mathrm{C}$ masih memberikan hasil terbaik yaitu selama 1,75 hari diikuti dengan kombinasi perlakuan $\mathrm{K}_{0} 25^{\circ} \mathrm{C}$ dan $\mathrm{K}_{0} 40^{\circ} \mathrm{C}$ yang memiliki nilai MGT yang sama yaitu selama 2,0 hari.

Pengamatan terhadap presentase perkecambahan memberikan hasil bahwa pemberian perendaman dengan asap cair memberikan persentase perkecambahan yang minimal sama atau lebih tinggi. Antara perlakuan $\mathrm{K}_{0} 25^{\circ} \mathrm{C}$ dan $\mathrm{K}_{1} 25^{\circ} \mathrm{C}$ dengan $\mathrm{K}_{0} 40^{\circ} \mathrm{C}$ dan $\mathrm{K}_{1} 40^{\circ} \mathrm{C}$ jumlah biji berkecambah dengan persentase yang sama yaitu masing-masing sebesar $100 \%$ dan $80 \%$. Tetapi hal yang berbeda terlihat pada kombinasi perlakuan $\mathrm{K}_{1} 30^{\circ} \mathrm{C}$ dan $\mathrm{K}_{1} 35^{\circ} \mathrm{C}$ yang memiliki persentase perkecambahan yang lebih besar dibandingkan dengan perlakuan tanpa perendaman dengan asap cair pada suhu yang sama $\left(\mathrm{K}_{0} 30^{\circ} \mathrm{C}\right.$ dan $\left.\mathrm{K}_{1} 35^{\circ} \mathrm{C}\right)$. Dengan demikian secara umum dapat dikatakan bahwa, secara kuantitatif dengan melihat parameter laju perkecambahan pemberian perlakuan dengan maupun tanpa perendaman asap cair belum memberikan hasil yang signifikan secara statistik. Selama eksperimen pengamatan terhadap beberapa parameter kualitatif juga dilakukan, diantaraanya terhadap munculnya plumula dan cabang akar (akar lateral). Untuk pengamatan plumula, pemberian perlakuan tanpa perendaman memunculkan plumula yang lebih cepat dibandingkan dengan perlakuan dengan pemberian perendaman asap cair, namun perbedaannya tidak begitu signifikan. Namun hal yang menarik terjadi pada perkembangan akar pada perlakuan perendaman asap cair menunjukkan hasil yang lebih baik dibandingkan dengan tanpa perendaman. Hal ini terlihat dari signifikansi munculnya akar lateral dalam waktu yang relatif lebih singkat dengan jumlah yang relatif lebih banyak pula. Hasil yang sama juga ditunjukkan oleh penelitian-penelitian sebelumnya pada tumbuhan lainnya seperti arabidopsis, gandum, tomat, okra dan buncis. (Light, et al., 2009., Kulkarni et al., 2011., Villaécija-Aguilar et al., 2019). Lebih jauh lagi Carbonnel et al. (2019) menunjukkan bahwa reseptor $\mathrm{KAI}_{2}$ yang berperan dalam pengaktivan jalur pensinyalan molekuler yang melibatkan karrikin sebagai ligan ternyata memiliki keragaman yang tinggi secara genetik pada varietas kacang Lotus japonicus. Sebagai sesama legum kondisi yang sama dapat mungkin terjadi pada kacang tanah yang terlihat dari cukup beragamnya respon pertumbuhan (dalam hal ini laju germinasi) dari kombinasi perlakuan yang diberikan.

\section{KESIMPULAN DAN SARAN}

Kombinasi perlakuan terbaik dalam mendorong laju perkecambahan biji kacang tanah adalah perlakuan tanpa perendaman dengan asap cair $\left(\mathrm{K}_{0} 25^{\circ} \mathrm{C}\right.$ dan $\left.40^{\circ} \mathrm{C}\right)$ dan perendaman dalam asap cair selama 1 jam $\left(\mathrm{K}_{1}\right)$ pada suhu $40^{\circ} \mathrm{C}$. Akan tetapi, apabila dibandingkan dengan lebih seksama, perlakuan $\mathrm{K}_{1}$ tidak hanya mendorong pertumbuhan perkecambahan tetapi juga perkembangannya yang terlihat dari terbentuknya cabang akar (akar lateral) yang lebih banyak. Dengan mempertimbangkan hasil pemberian perlakuan $\mathrm{K}_{2}$ dan $\mathrm{K}_{3}$ yang cenderung menghambat germinasi, maka untuk penelitian selanjutnya pemberian 
kombinasi perlakuan dapat dibatasi pada lama perendaman selama satu jam tetapi dengan memvariasikan konsentrasi asap cair yang digunakan. Analisis keragaman genetik reseptor $\mathrm{KAI}_{2}$ dari varietas kacang tanah yang digunakan dapat pula dilakukan untuk memberikan pemahaman lebih mendalam tentang keterlibatan senyawa exogenous growth factor dalam rangkaian jalur metabolik untuk memacu laju germinasi beserta pamaeter fisiologis lainnya.

\section{UCAPAN TERIMA KASIH}

Para penulis mengucapkan terima kasih kepada Pusat Penelitian dan Pengabdian Kepada Masyarakat, Politeknik Pertanian Negeri Kupang yang telah mendukung pelaksanaan penelitian ini melalui pembiayaan dana DIPA PNBP Penelitian Dasar Terapan (PDT) dengan nomor kontrak 01/P2M/DIPA.042.01.2. 401014/2019. Tak lupa pula penulis ucapkan terima kasih yang tulus kepada seluruh civitas akademika Politeknik Pertanian Negeri Kupang yang turut membantu dalam penelitian ini.

\section{DAFTAR PUSTAKA}

Al-Ansari, F. \& Ksiksi, T., 2016. A Quantitative Assessment of Germination Parameters: the Case of Crotalaria Persica and Tephrosia Apollinea. The Open Ecology Journal, 9(1), pp. 13-21.

Al-Mudaris, M. A., 1998. Notes on Various Parameter s Recording the Speed of Seed Germination. Journal of Agriculture in the Tropics and Subtropics, 99, pp. 147-154.

Badan Pusat Statistik (BPS). 2017. Produktivitas Kacang Tanah Menurut Provinsi 2017.

Carbonnel, S., Torabi, S., Griesmann, M., Bleek, E., Tang, Y., Buchka, S., Basso, V., Shindo, M., Wang, T. L., Udvardi, M., Waters, M. \& Gutjahr, C., 2019. Duplicated KAI2 receptors with divergent ligandbinding specificities control distinct developmental traits in Lotus japonicus. bioRxiv, pp. 1-54.

Chumpookam, J., Lin, H. L. \& Shiesh, C. C., 2012. Effect of smoke-water on seed germination and seedling growth of papaya (Carica papaya cv. Tainung No. 2). HortScience, 47(6), pp. 741-744.

Elsadek, M. A. \& Yousef, E. A. A., 2019. Smoke-water enhances germination and seedling growth of four horticultural crops. Plants, 8(104), pp. 1-17.

Flematti, G. R., Waters, M. T., Scaffidi, A., Merritt, D. J., Ghisalberti, E. L., Dixon, K. W. \& Smith, S. M., 2013.Karrikin and cyanohydrin smoke signals provide clues to new endogenous plant signaling compounds. Molecular Plant, 6(1), pp. 29-37.

Flematti, G. R., Dixon, K. W. \& Smith, S. M., 2015. What are karrikins and how were they "discovered" by plants?. BMC Biology, 13(108), pp. 1-7.

Ghebrehiwot, H. M., Kulkarni, M. G., Kirkman, K. P. \& Van Staden, J., 2008. Smoke-water and a smokeisolated butenolide improve germination and seedling vigour of Eragrostis tef (Zucc.) Trotter under high temperature and low osmotic potential. Journal of Agronomy and Crop Science, 194, pp. 270277.

Iqbal, M., Asif, S., Ilyas, N., Raja, N. I., Hussain, M., Shabir, S., Ashraf Faz, M. N. \& Rauf, A., 2016. Effect of Plant Derived Smoke on Germination and Post Germination Expression of Wheat (Triticum aestivum L.). American Journal of Plant Sciences, 07, pp. 806-813.

Kulkarni, M. G., Light, M. E. \& Van Staden, J., 2011. Plant-derived smoke: Old technology with possibilities for economic applications in agriculture and horticulture. South African Journal of Botany. 77, pp. 972-979.

Light, M. E., Daws, M. I. \& Van Staden, J., 2009. Smoke-derived butenolide: Towards understanding its Hal 72 Volume 20 Nomor 1 Tahun 2020 
Tang dkk: Analisis Laju Perkecambahan Kacang Tanah (Arachis hypogaea (L.) Merr.).

biological effects. South African Journal of Botany, 75, pp. 1-7.

Malone, Jamie. 2019. What is A Good Climate for Growing Peanuts?. https://living.thebump.com/goodclimate-growing-peanuts-5973.html. Web. 22 Apr. 2019.

Mussadad, Arif. 2005. Teknologi Produksi Kacang-kacangan dan Umbi-umbian. In: Achmad Winarto (eds). Teknologi Produksi Kacang Tanah di Lahan Alfisol Alkalis. Malang: Balai penelitian Tanaman Aneka kacang dan Umbi (BALITKABI). hal 15-20.

Rahmianna, Agustina Asri, Pratiwi, Herdina, dan Didik Harnowo. 2015. Kacang Tanah Inovasi Teknologi dan Pengembangan Produk. In: Achmad Winarto (eds). Budidaya Kacang Tanah. Malang: Balai penelitian Tanaman Aneka kacang dan Umbi (BALITKABI). hal 133-169.

Soós, V., Badics, E., Incze, N. \& Balázs, E., 2019. Fire-Borne Life: A Brief Review of Smoke-Induced Germination. Natural Product Communications, pp. 1-5.

Trustinah. 2015. Kacang Tanah Inovasi Teknologi dan Pengembangan Produk. In : Achmad Winarto (eds). Sumber Daya Genetik Kacang Tanah. Malang: Balai penelitian Tanaman Aneka kacang dan Umbi (BALITKABI). hal 60-83.

van Staden, J., Sparg, S. G., Kulkarni, M. G. \& Light, M. E., 2006. Post-germination effects of the smokederived compound 3-methyl-2H-furo[2,3-c]pyran-2-one, and its potential as a preconditioning agent. Field Crops Research, 98, pp. 98-105.

Villaécija-Aguilar, J. A., Hamon-Josse, M., Carbonnel, S., Kretschmar, A., Schmidt, C., Dawid, C., Bennett, T. \& Gutjahr, C., 2019. SMAX1/SMXL2 regulate root and root hair development downstream of KAI2-mediated signalling in Arabidopsis. PLOS Genetics, 15(8), pp. 1-27.

Zhou, J., Teixeira da Silva, J. A. \& Ma, G., 2014. Effects of smoke water and karrikin on seed germination of 13 species growing in China. Central European Journal of Biology, 9(11), pp. 1108-1116. 